\title{
Major, Minor and Trace Element Analysis of Baobab Fruit and Seed by Instrumental Neutron Activation Analysis Technique
}

\author{
Isaac Kwasi Baidoo ${ }^{1,2}$, John Justice Fletcher ${ }^{3}$, Linda Osei Poku², Apori Ntiforo ${ }^{3}$, \\ Jude Bayor Simons $^{3}$, Nicholas Sakyitey Opata ${ }^{1}$, Robert Ekow Quagraine ${ }^{1}$ \\ ${ }^{1}$ Nuclear Reactors Research Centre, National Nuclear Research Institute, Ghana Atomic Energy Commission, Legon, Ghana; \\ ${ }^{2}$ Department of Nuclear Sciences and Applications, School of Nuclear and Allied Sciences, University of Ghana, Legon, Ghana; \\ ${ }^{3}$ Faculty of Applied Sciences, Physics Department, University for Development Studies, Navrongo, Ghana. \\ Email: baidooisaac51@yahoo.co.uk
}

Received May $2^{\text {nd }}, 2013$; revised June $2^{\text {nd }}, 2013$; accepted June $9^{\text {th }}, 2013$

Copyright (C) 2013 Isaac Kwasi Baidoo et al. This is an open access article distributed under the Creative Commons Attribution License, which permits unrestricted use, distribution, and reproduction in any medium, provided the original work is properly cited.

\begin{abstract}
Mineral element compositions of Baobab fruit and seed have been determined using Instrumental Neutron Activation Analysis. Total of 18 mineral elements were determined of which 10 are not normally reported using other methods. The concentrations of heavy metals were: Arsenic $<0.06$ and $<0.04$, Mercury $<0.04$ and $<0.04 \mathrm{Hg}$ and Cadmium $<0.08$ and $<0.04$ respectively for the seeds and the fruit. The average concentration of trace elements in the seed were; Aluminium $(11.50 \mu \mathrm{g} / \mathrm{g})$, Barium $(17.3 \mu \mathrm{g} / \mathrm{g})$, Bromine $(2.45 \mu \mathrm{g} / \mathrm{g})$, Cobalt $(0.07 \mu \mathrm{g} / \mathrm{g})$, Copper $(28.6 \mu \mathrm{g} / \mathrm{g})$, Iron $(<42$ $\mu \mathrm{g} / \mathrm{g})$, Iodine $(<0.04 \mu \mathrm{g} / \mathrm{g})$, Manganese $(17.7 \mu \mathrm{g} / \mathrm{g})$, Sodium $(23.53 \mu \mathrm{g} / \mathrm{g})$, Vanadium $(0.035 \mu \mathrm{g} / \mathrm{g})$, and Zinc $(12.06$ $\mu \mathrm{g} / \mathrm{g})$, while the average concentrations of Aluminium $(27.74 \mu \mathrm{g} / \mathrm{g})$, Barium $(13.10 \mu \mathrm{g} / \mathrm{g})$, Bromine $(3.01 \mu \mathrm{g} / \mathrm{g})$, Cobalt $(0.08 \mu \mathrm{g} / \mathrm{g})$, Copper $(14.9 \mu \mathrm{g} / \mathrm{g})$, Iron $(26.05 \mu \mathrm{g} / \mathrm{g})$, Iodine $(0.27 \mu \mathrm{g} / \mathrm{g})$, Manganese $(7.05 \mu \mathrm{g} / \mathrm{g})$, Sodium $(52.06 \mu \mathrm{g} / \mathrm{g})$, Vanadium $(0.08 \mu \mathrm{g} / \mathrm{g})$, and Zinc $(0.79 \mu \mathrm{g} / \mathrm{g})$ were determined for the dried fruit pulp. The mineral concentrations of the baobab fruit and seed were characterized with high concentration of potassium, calcium, magnesium and substantive amount of chlorine $[\mathrm{K}(21350 \mu \mathrm{g} / \mathrm{g}), \mathrm{Ca}(3170 \mu \mathrm{g} / \mathrm{g}), \mathrm{Mg}(2310 \mu \mathrm{g} / \mathrm{g})$ and $\mathrm{Cl}(211 \mu \mathrm{g} / \mathrm{g})$, for the fruit pulp and $\mathrm{K}$ $(12240 \mu \mathrm{g} / \mathrm{g}), \mathrm{Ca}(2360 \mu \mathrm{g} / \mathrm{g}), \mathrm{Mg}(4720 \mu \mathrm{g} / \mathrm{g})$ and $\mathrm{Cl}(88.6 \mu \mathrm{g} / \mathrm{g})$, for the seed]. The fruits and seeds present useful source of mineral needs for the indigenous African community where the trees are found and may be recommended as food supplement due to high content of calcium, magnesium and potassium.
\end{abstract}

Keywords: Heavy Metals; Baobab; INAA; Potassium; Calcium; Magnesium

\section{Introduction}

Sidibe and Williams [1] indicated that, the African bao$\mathrm{bab}$ and its related species belong to the family Bombacaceae and the genus Adansonia and that baobab is generally regarded as fruit-bearing forest tree. The physical description of the baobab tree is mostly characterized by its massive size, reaching to a height of about $18-25 \mathrm{~m}$ and producing a rounded crown and showing a stiff branching habit. The trunk is swollen and stout, up to 10 $\mathrm{m}$ in diameter. The Baobab trees are generally reported to be found in countries of Southern Africa, such as Botswana, Mozambique, Namibia, South Africa and Zimbabwe [2] and other African countries including Ghana. In Ghana the distributions of Baobab treesin Saakpuli; Northern region of Ghana were described as form- ing an outstanding floral feature of the landscape of Saakpuli by [3] in his Archeological studies of the area. The studies further enumerated a number of uses for all parts of the baobab tree; while the powder from the dried fruit is either eaten raw or prepared into porridge to be serve as breakfast, the seed is fried and grounded into powder and used in preparing soup (just as ground nuts). The root and the bark are used for medicinal purposes including chest diseases. Other literatures [4-6] have reported on the native usage and application of baobab as food and medicine; the Baobab fruit pulps in a form of powder are dissolved in water in order to prepare drinks. For most traditional medicinal applications, the Baobab fruit drink is generally recommended for pregnant women and in some instances used in preparation of 
baby food for baby's nourishment [4]. Galil and Tal-Dia et al. [5,6] independently demonstrated in 1996 and 1997 respectively, that an aqueous solution made from baobab fruit pulp was more effective than the traditional " $W H O$ solution" for rehydration of children affected with diarrhea.

The multipurpose nature of the baobab tree had been recognized by the Forestry Department of the Food and Agriculture Organization of the UN (FAO) to issue information on the species [7] and have since attracted the International Centre for Research in Agro forestry (ICRAF) also to continue promote its use as a multipurpose species.

However, reviewed literatures have revealed a great variation in reported values of nutritional contents of baobab parts. Many reasons had been assigned to these variations [8]; he further recommended that, more attention should be given to accuracy and precision of the analytical methods employed for the analysis in order to streamline critical comparison and analysis. It is on this basis that Instrumental neutron Activation Analysis was employed for more accurate and independent (mineral analysis free from pre-chemical treatment or addition) elemental analysis of Baobab seed and fruit pulp in order to inform proper regulation or proportionate usage or supplement recommendation.

Instrumental Neutron Activation Analysis (INAA) is a method for the determination of elements and its quantity (relative concentration), based on the conversion of stable nuclei to radioactive nuclei through nuclear reactions using a suitable neutron source (isotopic neutron source, accelerator neutron source and reactor neutron source). Suitable (appropriate irradiation scheme) activation followed by the instrumental detection (measurement) of the reaction product(s) of the analyte and the calibration standard may enable detection and quantification of over 20 minerals (elements). Particular advantages to the application of INAA for the analysis of baobab fruits and seeds include; samples do not have to undergo any chemical treatment; this would eliminate possible external contamination. INAA is a technique for multi-element determination and above all provides elemental sensitivities capable of measuring major, trace and ultra trace down to part per billion levels [9], hence more mineral elements are likely to be detected and quantified.

Despite the numerous literatures reporting on the chemical, nutritional values, and health properties of baobab, there were scanty literatures on the analysis of Baobabs(the fruits or the seed) found in Ghana (we found no data on those found in Ghana). More so, few elemental compositions of the Baobab (fruits or seeds) were reported by the available literatures [1,10-12]. This work provided a full mineral composition of Baobab fruits and seeds and reported on as many mineral (elements) as were detected. We discussed the major benefits of the mineral elements with respect to traditionally recommended food sources for their nutritional values.

\section{Materials and Method}

\subsection{Sampling and Sample Preparation}

Ten Baobab trees were sampled at random at Bondunia Community adjacent to Navrongo Secondary School a suburb of Navrongo Township, Northern Region of Ghana. The samples were then bag into black plastic polyethylene carrier and transported to Ghana Research Reactor-1 (GHARR-1) laboratory. At the laboratory, dried Baobab pods were washed with distilled water to remove any particulate matter which might have accumulated on pod and dried in the lab for two days. The dried pods were then cracked open with kitchen knife and the fruit content (lumped) scooped from the pod. The seeds were thoroughly washed with distilled water to dissociate the fruit particle from the seed to ensure separate and independent analysis without cross contamination. Each (the fruit lumps and the seeds) were blended to smooth powder using kitchen blender (with titanium blade).

$200 \mathrm{mg}$ each of the samples and control materials (National Bureau of Standards (NBS), Standard Reference Material (SRM) 1572 Citrus Leaves) were weighed (6 replica each) and wrapped in a transparent polyethelene film to be irradiated for short-live, medium-live and long-lived radionuclide(s) (elements). The samples were further encapsulated into irradiation capsules and heat sealed for neutron activation (irradiation).

\subsection{Irradiations, Counting, Spectrum Evaluation and Quantitative Analysis}

All the samples together with sample controls NBS SRM 1572, Citrus leaves, were irradiated in the Miniature Neutron Source Reactor (MNSR), Ghana Research Reactor-1 (GHARR-1). The irradiations were done under an average neutron flux of $5.0 \times 10^{11} \mathrm{n} \mathrm{cm}^{-2} \cdot \mathrm{s}^{-1}$. Table 1 represents the nuclear data and irradiation scheme used for the elemental determination in this work. An irradiation time of 5 minutes were applied for the determination of short lived radionuclides (elements), 1 to 4 hours for the determination of medium-lived and long-lived radionuclides.

Gamma spectrometry measurement of induced radio nuclide(s) were performed by a PC-based $\gamma$-ray spectrometry set-up. It consists of an N-type High purity Germanium detector (HpGe-coaxial type) coupled to a computer based multi-channel analyzer (MCA) via electronic modules. The relative efficiency of the detector is 
Table 1. Nuclear data and irradiation scheme used for the elemental analysis [13].

\begin{tabular}{|c|c|c|c|}
\hline Element & $\begin{array}{l}\text { Nuclear } \\
\text { Reaction }\end{array}$ & Energy (keV), Half Life & $\begin{array}{c}\text { Irradiation Scheme, } \\
\text { Irradiation and Counting Time }\end{array}$ \\
\hline Al & ${ }^{27} \mathrm{Al}(\mathrm{n}, \gamma)^{28} \mathrm{Al}$ & $1778.9,2.4 \mathrm{~m}$ & Short, $5 \mathrm{~m}, 10 \mathrm{~m}$ \\
\hline As & $\left.{ }^{75} \mathrm{As} \mathrm{n}, \gamma\right)^{76} \mathrm{As}$ & $559.1,26.3 \mathrm{~h}$ & Medium, $60 \mathrm{~m}, 10 \mathrm{~m}$ \\
\hline Ba & ${ }^{137} \mathrm{Ba}(\mathrm{n}, \gamma){ }^{139} \mathrm{Ba}$ & $165,84.6 \mathrm{~m}$ & Short, $5 \mathrm{~m}, 10 \mathrm{~m}$ \\
\hline $\mathrm{Br}$ & ${ }^{81} \mathrm{Br}(\mathrm{n}, \gamma){ }^{82} \mathrm{Br}$ & $776,35.3 \mathrm{~h}$ & Medium, $60 \mathrm{~m}, 10 \mathrm{~m}$ \\
\hline Ca & ${ }^{48} \mathrm{Ca}(\mathrm{n}, \gamma){ }^{49} \mathrm{Ca}$ & $3084.4,8.72 \mathrm{~m}$ & Short, $5 \mathrm{~m}, 10 \mathrm{~m}$ \\
\hline Cd & ${ }^{114} \mathrm{Cd}(\mathrm{n}, \gamma){ }^{115} \mathrm{Cd}$ & $336,53.5 \mathrm{~h}$ & Medium, $60 \mathrm{~m}, 10 \mathrm{~m}$ \\
\hline $\mathbf{C l}$ & ${ }^{37} \mathrm{Cl}(\mathrm{n}, \gamma){ }^{38} \mathrm{Cl}$ & $1642,37.2 \mathrm{~m}$ & Short, $5 \mathrm{~m}, 10 \mathrm{~m}$ \\
\hline Co & ${ }^{59} \mathrm{Co}(\mathrm{n}, \gamma){ }^{60} \mathrm{Co}$ & $1173.2 / 1332.4,5.27 \mathrm{y}$ & long, $4 \mathrm{~h}, 5 \mathrm{~h}$ \\
\hline $\mathbf{C u}$ & ${ }^{65} \mathrm{Cu}(\mathrm{n}, \gamma){ }^{66} \mathrm{Cu}$ & $1039.4,5.1 \mathrm{~m}$ & Short, $5 \mathrm{~m}, 10 \mathrm{~m}$ \\
\hline $\mathbf{F e}$ & ${ }^{58} \mathrm{Fe}(\mathrm{n}, \gamma){ }^{59} \mathrm{Fe}$ & $1099.2,44.5 \mathrm{~d}$ & long, $4 \mathrm{~h}, 5 \mathrm{~h}$ \\
\hline Hg & ${ }^{198} \mathrm{Hg}(\mathrm{n}, \gamma){ }^{197} \mathrm{Hg}$ & $77.39,64.1 \mathrm{~h}$ & Medium, $60 \mathrm{~m}, 10 \mathrm{~m}$ \\
\hline I & ${ }^{127} \mathrm{I}(\mathrm{n}, \gamma)^{128} \mathrm{I}$ & $442,25 \mathrm{~m}$ & Short, $5 \mathrm{~m}, 10 \mathrm{~m}$ \\
\hline $\mathbf{K}$ & ${ }^{41} \mathrm{~K}(\mathrm{n}, \gamma){ }^{42} \mathrm{~K}$ & $1524.58,12 \mathrm{~h}$ & Medium, $60 \mathrm{~m}, 10 \mathrm{~m}$ \\
\hline Mg & ${ }^{26} \mathrm{Mg}(\mathrm{n}, \gamma)^{27} \mathrm{Mg}$ & $1014.4,9.46 \mathrm{~m}$ & Short, $5 \mathrm{~m}, 10 \mathrm{~m}$ \\
\hline Mn & ${ }^{55} \mathrm{Mn}(\mathrm{n}, \gamma){ }^{56} \mathrm{Mn}$ & $1810.7,2.58 \mathrm{~h}$ & Short, $5 \mathrm{~m}, 10 \mathrm{~m}$ \\
\hline $\mathrm{Na}$ & ${ }^{23} \mathrm{Na}(\mathrm{n}, \gamma){ }^{24} \mathrm{Na}$ & $1368.6 / 2754.1,15 \mathrm{~h}$ & Medium, $60 \mathrm{~m}, 10 \mathrm{~m}$ \\
\hline S & ${ }^{36} \mathrm{~S}(\mathrm{n}, \gamma){ }^{37} \mathrm{~S}$ & $3105,5.05 \mathrm{~m}$ & Short, $5 \mathrm{~m}, 10 \mathrm{~m}$ \\
\hline $\mathbf{V}$ & ${ }^{51} \mathrm{~V}(\mathrm{n}, \gamma){ }^{52} \mathrm{~V}$ & $1435,3.75 \mathrm{~m}$ & Short, $5 \mathrm{~m}, 10 \mathrm{~m}$ \\
\hline Zn & ${ }^{64} \mathrm{Zn}(\mathrm{n}, \gamma){ }^{65} \mathrm{Zn}$ & $1115,344 \mathrm{~d}$ & long, $4 \mathrm{~h}, 5 \mathrm{~h}$ \\
\hline
\end{tabular}

$40 \%$. It energy resolution is $1.8 \mathrm{keV}$ at a gamma-ray ( $\gamma$-rays) energy of $1332 \mathrm{keV}$ of ${ }^{60} \mathrm{Co}$ source. The data acquisition and identification of $\gamma$-rays of product radionuclide(s) were identified by their $\gamma$-ray energy (ies) via ORTEC MAESTRO-32.

Gamma spectrum evaluation and quantitative analysis of each sample and control were done by multipurpose $\gamma$-ray spectrum analysis software; WinSPAN-2010 version 2.10 which works on the basis of relative comparator methodology.

\section{Result and Discussion}

\section{Nutritional Composition of Baobab Fruit Pulp and Seed}

The range of reported values for National Bureau of Standards (NBS: Citrus leaves) as shown on Table 2 indicates an average accuracy of about $\pm 10 \%$ in terms of the relative deviation from the certified values (certified values of constituent elements on the certificate sheet). Table 3 indicates the elemental content of baobab dried fruit pulp and seed compared to other elemental results obtained from [1,10-12]. The average range of concentrations of the elements detected in this work compares very well in most cases with other works, however, there were a number of disparities for which Chadare et al. [8] have associated to soil type, geographical location of the
Table 2. Quality control results for National Bureau of Standards (NBS) Standard Reference Material (SMS) citreous leaves.

\begin{tabular}{ccc}
\hline \multicolumn{3}{c}{ NBS: SRM Validations n = 3 } \\
\hline Element & Citreous Leaves \\
Al & $75.33-86.54$ & Reported \\
As & $3.61-4.32$ & $92 \pm 15$ \\
Ba & $17.94-24.22$ & 21 \\
Br & $9.32-14.64$ & 8.2 \\
Ca & $28,761-31,002$ & $31,500 \pm 1000$ \\
Cd & $<0.06$ & $0.03 \pm 0.001$ \\
Cl & $300.2-467$ & 414 \\
Co & $0.05-0.15$ & 0.02 \\
Cu & $17.3-19.7$ & $16.5 \pm 1.0$ \\
Fe & $60.5-101.2$ & $90 \pm 10$ \\
Hg & $<0.10$ & $0.08 \pm 0.02$ \\
I & $1.03-2.33$ & $1.84 \pm 0.03$ \\
K & $1726-20,321$ & $18,200 \pm 600$ \\
Mg & $3898-5567$ & $5800 \pm 300$ \\
Mn & $16.45-22.41$ & $23 \pm 2$ \\
Na & $27.05-35.32$ & $160 \pm 20$ \\
S & $2816-662$ & $4070 \pm 90$ \\
V & $0.10-0.15$ & NR \\
Zn & $17.88-32.25$ & $29 \pm 2$ \\
\hline & & \\
\hline & & \\
\hline
\end{tabular}


Table 3. The trace element content of Baobab dried fruit pulp and seed compared with the trace element data from three other Baobab fruit pulp samples reported by [1,10-12]; Minimum and maximum results obtained from triplicate of each sample analyzed.

\begin{tabular}{|c|c|c|c|c|c|c|c|c|c|c|}
\hline \multirow[b]{3}{*}{ Elements } & \multicolumn{6}{|c|}{ This Work } & \multirow{3}{*}{$\begin{array}{c}{[1]} \\
\text { Seed }\end{array}$} & \multirow{3}{*}{$\begin{array}{l}\text { [10] } \\
\text { Fruit Pulp }\end{array}$} & \multirow{3}{*}{$\begin{array}{c}\text { [11] } \\
\text { Fruit pulp }\end{array}$} & \multirow{3}{*}{$\begin{array}{c}\text { [12] } \\
\text { Fruit Pulp }\end{array}$} \\
\hline & \multicolumn{3}{|c|}{ Seed } & \multicolumn{3}{|c|}{ Fruit Pulp } & & & & \\
\hline & Min & Max & Average & Min & Max & Average & & & & \\
\hline Al & 9.782 & 13.24 & 11.5 & 22.62 & 31.32 & 27.74 & NR & NR & NR & NR \\
\hline As & - & - & $<0.06$ & - & - & $<0.01$ & NR & NR & NR & NR \\
\hline $\mathbf{B a}$ & 15.45 & 21.6 & $' 17.3$ & 10.32 & 17.5 & 13.1 & NR & NR & NR & NR \\
\hline $\mathrm{Br}$ & 2.056 & 2.75 & 2.464 & 2.882 & 4.432 & 3.009 & NR & NR & NR & NR \\
\hline Ca & 1652 & 3068 & 2360 & 2549 & 3791 & 3170 & 3950 & 2160 & 2950 & $3000-2750$ \\
\hline Cd & - & - & $<0.08$ & - & - & $<0.04$ & NR & NR & NR & $<3$ \\
\hline Cl & 76.51 & 100.1 & 88.6 & 182.3 & 239.7 & 211 & NR & NR & NR & NR \\
\hline Co & 0.062 & 0.078 & 0.07 & 0.048 & 0.083 & 0.067 & NR & NR & NR & NR \\
\hline $\mathrm{Cu}$ & 24.12 & 32.5 & 28.6 & 12.53 & 18.95 & 14.9 & NR & NR & 16 & NR \\
\hline $\mathbf{F e}$ & - & - & $<42$ & 21.73 & 30.12 & 26.05 & 18.3 & 29.2 & 90.3 & $7.02-6.5$ \\
\hline Hg & - & - & $<0.04$ & - & - & $<0.04$ & NR & NR & NR & $<0.1$ \\
\hline I & - & - & $<0.46$ & 0.21 & 0.33 & 0.27 & NR & NR & NR & NR \\
\hline $\mathbf{K}$ & 11,469 & 13,011 & 12,240 & 18,349 & 24,064 & 21,350 & NR & 7260 & 12,400 & $31,000-20,000$ \\
\hline Mg & 4550 & 4890 & 4720 & 2208 & 2413 & 2310 & 3520 & 3000 & 900 & NR \\
\hline Mn & 14.83 & 21.55 & 17.7 & 5.962 & 8.247 & 7.05 & 10.6 & NR & NR & $7.5-6$ \\
\hline $\mathrm{Na}$ & 18.76 & 26.32 & 23.53 & 47.63 & 58.39 & 52.06 & 19.6 & 7.9 & 270.9 & $6-2$ \\
\hline $\mathbf{V}$ & 0.029 & 0.053 & 0.035 & 0.064 & 0.093 & 0.083 & NR & NR & NR & NR \\
\hline Zn & 11.94 & 17.3 & 12.06 & 0.55 & 1.03 & 0.79 & 25.7 & NR & 18 & NR \\
\hline
\end{tabular}

Min: Minimum; Max: Maximum; NR: Not Reported.

baobab, probable genetic effect, sample quality, analytical method employed, etc. However, this method has been able to determine concentration of over 10 more mineral elements for Baobab fruits and seeds in addition to what are normally reported using other methods [14,15] and this is significant for mineral element data base of Baobab fruits and seeds.

In all about 18 elements were detected and quantified in which 11 are found in traces, 5 found as major component and 3 as heavy metal. The heavy metals were found to be $<0.06$ for As, $<0.04$ for $\mathrm{Hg}$ and $<0.08$ for $\mathrm{Cd}$ in the seed sample and $<0.04 \mathrm{As},<0.04 \mathrm{Hg}$ and $<0.04 \mathrm{Cd}$ in the dried fruit pulp. The virtual absence of these heavy metals (even if they exist, might be within the recommended limit) is welcoming news for users and continual use of the fruit without any risk of heavy metal contaminations or any adverse health complications.

As many as 11 trace elements were detected and quan- tified accordingly. The average concentration of trace elements in the Baobab seeds were; $\mathrm{Al}(11.50 \mu \mathrm{g} / \mathrm{g}), \mathrm{Ba}$ (17.3 $\mu \mathrm{g} / \mathrm{g}), \mathrm{Br}(2.45 \mu \mathrm{g} / \mathrm{g}), \mathrm{Co}(0.07 \mu \mathrm{g} / \mathrm{g}), \mathrm{Cu}(28.6$ $\mu \mathrm{g} / \mathrm{g}), \mathrm{Fe}(<42 \mu \mathrm{g} / \mathrm{g}), \mathrm{I}(<0.04 \mu \mathrm{g} / \mathrm{g}), \mathrm{Mn}(17.7 \mu \mathrm{g} / \mathrm{g}), \mathrm{Na}$ $(23.53 \mu \mathrm{g} / \mathrm{g}), \mathrm{V}(0.035 \mu \mathrm{g} / \mathrm{g})$, and $\mathrm{Zn}(12.06 \mu \mathrm{g} / \mathrm{g})$; and Al $(27.74 \mu \mathrm{g} / \mathrm{g}), \mathrm{Ba}(13.10 \mu \mathrm{g} / \mathrm{g}), \mathrm{Br}(3.01 \mu \mathrm{g} / \mathrm{g})$, Co $(0.08 \mu \mathrm{g} / \mathrm{g}), \mathrm{Cu}(14.9 \mu \mathrm{g} / \mathrm{g}), \mathrm{Fe}(26.05 \mu \mathrm{g} / \mathrm{g}), \mathrm{I}(0.27$ $\mu \mathrm{g} / \mathrm{g}), \mathrm{Mn}(7.05 \mu \mathrm{g} / \mathrm{g}), \mathrm{Na}(52.06 \mu \mathrm{g} / \mathrm{g}), \mathrm{V}(0.08 \mu \mathrm{g} / \mathrm{g})$, and $\mathrm{Zn}(0.79 \mu \mathrm{g} / \mathrm{g})$ were determined and quantified for the dried fruit pulp.

The presence of minerals in all body tissues and fluids, and its necessity for the maintenance of certain physicochemical processes which are found to be essential to life as well as the important roles it plays in many activities in the body had been discussed by Malhotra [16]. This work is intended to discuss in brief, the importance of minerals detected in the baobab fruit in relation to availability (other food sources able to provide similar min- 
eral) of these mineral in the food of the local indigenes.

These elements are necessary chemical elements that are needed in minute quantities for the proper growth, development, and physiology of an organism. Some notable importances of these trace elements are described below:

Despite the fact that, trace elements are needed by organisms for proper functioning, a number of them require the presence of others. Together they work in composite unit to achieve optimal results (absorption into the blood stream). For example copper is essential for zinc, iron and vitamin $\mathrm{C}$ functioning. Copper together with iron and zinc is responsible for releasing energy in the cells [17] and contributes to proper functioning of many antioxidants. Copper has been found to be not only responsible for collagen productions, but also the absorption of iron, regulation of cholesterol level and production of neuro active chemicals. Iron together with other major nutrients (Ca, $\mathrm{Mg}, \mathrm{K}$ etc.) are need for red blood cell formation in order to release energy in muscles, in other words zinc is very necessary for the body in varieties of ways including manufacturing of DNA, wound healing, maintaining strong immune system for fighting cold, flu, and other infections [18].

The Baobab dried pulp was also found to contain iodine in substantive amount $(0.27 \mu \mathrm{g} / \mathrm{g})$. Iodine is needed to make thyroid hormones, which are necessary for maintaining normal metabolism in all cells of the body, a number of reports also suggests that, iodine may have a number of important functions in the body unrelated to thyroid function that might help people with a wide variety of conditions [17]. Manganese like other trace elements enables the body to utilize vitamin C, B1, biotin as well as choline. Hays and Swenson [19] demonstrated and discussed manganese deficiency effect or defects in animals; however deficiency disease or symptoms are quite unknown in humans.

Magnesium has been identified as an active component of several enzyme systems in which thymine pyrophosphate is a cofactor. It is also found to be a constituent of bones, teeth, and enzyme cofactor [20]. One other significant observation about the baobab fruit and seed was the fact that the average sodium $(23.53 \mu \mathrm{g} / \mathrm{g}$; seed and $52.06 \mu \mathrm{g} / \mathrm{g}$; fruit pulp respectively), bromine (2.46 $\mu \mathrm{g} / \mathrm{g}$ for seed and $3.01 \mu \mathrm{g} / \mathrm{g}$ for fruit pulp) and aluminium $(11.50 \mu \mathrm{g} / \mathrm{g}$ for seed and $27.74 \mu \mathrm{g} / \mathrm{g}$ for fruit pulp) contents of the baobab were relatively low, this is a further indication that the baobab may generally be good for consumption by all including obese and diabetic people. One other micro nutrient detected in the baobab seed and the pulp was vanadium $(0.04 \mu \mathrm{g} / \mathrm{g}$ and $0.09 \mu \mathrm{g} / \mathrm{g}$ respectively for seed and fruit pulp). In a study [21] involving both diabetic and non-diabetic rats, vanadium com- pounds were shown to increase bone formation without any adverse health effects. Vanadium is known to have a role in the regulation of sodium and the metabolism of glucose and sugar. It has also been shown to promote bone health without negative side effect. However, other literature [22] indicates that the essentiality of vanadium in man had been hypothesized without demonstration.

Four elements were found in major compositions; $\mathrm{Cl}$ $(211 \mu \mathrm{g} / \mathrm{g}), \mathrm{K}(21350 \mu \mathrm{g} / \mathrm{g}), \mathrm{Ca}(3170 \mu \mathrm{g} / \mathrm{g})$, and $\mathrm{Mg}$ $(2310 \mu \mathrm{g} / \mathrm{g})$ for pulp and $\mathrm{Cl}(88.6 \mu \mathrm{g} / \mathrm{g}), \mathrm{K}(12240 \mu \mathrm{g} / \mathrm{g})$, $\mathrm{Ca}(2360 \mu \mathrm{g} / \mathrm{g})$, and $\mathrm{Mg}(4720 \mu \mathrm{g} / \mathrm{g})$ for the seed.

Major mineral elements in Baobab have been compared [23] to fruits sources like; avocado, apricot (dried), spinach, banana etc., and food sources like; bread, yoghurt, milk and spinach etc. which have indicated that, the baobab fruits and seeds have more mineral content especially magnesium and potassium. These rich mineral component of Baobab fruit and seed may not only be of particular interest to makers of products for vegetarians and vegans, but also baobab's high potassium content may be of particular interest to makers of sports and fitness products. The relatively high magnesium content found in the baobab fruit and the seed indicates that the Baobab, may be a good food supplement for people with bone, heart and high pressure diseases symptoms as magnesium has been linked to bone health, heart health and lowering of high blood pressure [23]. Potassium is also important for many aspects of health including the nervous system and muscle function. Generally one experiences loss of chloride in association with sweating and/or diarrhoea after an excessive vomiting. The only possible explanation to the fact that baobab aqueous solution performed much better than "WHO solution" for rehydration of children affected with diarrhea [5,6], may be attributed to the relatively high content of chlorine in baobab fruit pulp which replenish the loss of chlorine in the body as a result of vomiting or sweating during diarrhoea.

Without mentioning the specifics and their relative quantities, natural sources of these trace elements may include but not limited to; beef, liver, crab, milk, peanut butter, seafood, lamb, turkey ham, pork chicken, eggs, oyster, dried beans, split peas, fortified cereals, wheat germ, brown rice, oatmeal, bran flakes, banana, sunflower butter, chocolate, tuna etc. However, these sources are either unavailable or quite expensive to the indigenous African communities in which Baobab trees are found and hence Baobab might be the main (or cheapest) source of these all important micro and macro nutrients.

The very many macro and micro nutritional contents of Baobab fruit pulp and seed makes them very useful for making food products like: fruit smoothies, breakfast cereals, healthy snacks, ice creams, jams, sauces, sports and fitness food, vitamin and mineral fortification mixes 
as well as health supplements.

\section{Conclusion and Recommendations}

Instrumental neutron activation analysis had been used to determine mineral composition of baobab fruit pulp and seed. As many as 18 mineral elements were detected and quantified accordingly based on relative comparator method. Over 10 more mineral elements have been reported in addition to what are usually reported using other methods. This is very significant as the multi-element determination of INAA technique was greatly harnessed to this effect. This work was (to the best of the authors' knowledge) the first mineral (elemental) analysis on Baobab fruits and seeds found in Ghana. The rich mineral content of Baobab fruits and seeds makes them useful mineral source for indigenous African communities in which Baobab trees are found and hence may be a good mineral supplement to be recommended for pregnant/ nursing mothers especially; calcium, magnesium and potassium which are mostly needed for building healthy bones and for baby's nourishment.

\section{Acknowledgements}

The authors do express their sincere appreciation to $\mathrm{Mr}$. Edward Yeyeh of the Works and Physical Development Department of the University for Development Studies, for the invaluable support offered in the collection of samples. We also recognize the cordial relationship rendered to us by the staffs of National Reactors Research Center, National Nuclear Research Institute, Ghana Atomic Energy Commission.

\section{REFERENCES}

[1] M. Sidibe and J. T. William, "Baobab Adansonia digitata," International Centre for Underutilized Crops, Southampton, 2002.

[2] K. C. Palgrave, M. C. Palgrave and P. C. Palgrave, "Everyone's Guide to Trees of South Africa," 4th Edition, Struik New Holland Publishers, Cape Town, 2000.

[3] J. A. Okoro, "Some Archeological Indication of Slave Market and Baobab Tree of Saakpuli, Nothern Region, Ghana," University of Ghana, Legon, 2002.

[4] A. Prentice, M. A. Laskey, J. Shaw, G. J. Hudson, K. C. Day, L. M. A. Jarjou, B. Dibba and A. A. Paul, "The Calcium and Phosphorus Intakes of Rural Gambian Women during Pregnancy and Lactation," British Journal of Nutrition, Vol. 69, No. 3, 1993, pp. 885-896. doi:10.1079/BJN19930088

[5] N. E. Galil, "Evaluaion of Baobab (Gonglase) Solution for Home Management of Diarrhea in Sudanese Children," Ph.D. Thesis, Khartoum University, Khartoum, 1996, $152 \mathrm{p}$.
[6] A. Tal-Dia, K. Toure, O. Sarr, M. Sarr, M. F. Cisse, P. Garnier and I. Wone, "A Baobab Solution for the Prevention and Treatment of Acute Dehydration in Infantile Diarrhea," Dakar Medical, Vol. 42, No. 1, 1997, pp. 68-73.

[7] FAO, "Traditional Food Plants," FAO Food and Nutrition Paper 42, FAO, Rome, 1988.

[8] F. J. Chadare, A. R. Linnemann, J. D. Hounhouigan, M. J. R. Nout and M. A. J. S. Van Boekel, "Baobab Food Products: A Review on their Composition and Nutritional Value," Critical Reviews in Food Science and Nutrition, Vol. 49, No. 3, 2009, pp. 254-274.

[9] L. Hilde, "Semi-Centennial Lecture," The Opening of the 7th International Conference Modern Trends in Activation Analysis, Copenhagen, 23 June 1986.

[10] L. P. Sena, D. J. Vanderjagt, C. Rivera, A. T. C. Tsin, I. Muhamadu, O. Mahamadou, M. Millson, A. Pastuszyn and R. H. Glew, "Analysis of Nutritional Components of Eight Famine Foods of the Republic of Niger," Plant Foods for Human Nutrition, Vol. 52, No. 1, 1998, pp. 1730.

[11] M. A. Osman, "Chemical and Nutrient Analysis of Baobab (Adansonia digitata) Fruit and Seed Protein Solubility," Plant Foods for Human Nutrition, Vol. 59, No. 1, 2004, pp. 29-33. doi:10.1007/s11130-004-0034-1

[12] Baobab Fruit Company, Senegal, "Baobab (A. digitata L.)," Dried Fruit Pulp, Data Sheet, 2010.

http://www.minvita.co.uk/upload/file/Baobab\%20Data\%2 OSheet.pdf

[13] IAEA-TECDOC-564, "Practical Aspects of Operating NAA Laboratory,” IAEA, Vienna, 1990, pp. 197-237.

[14] E. B. Sandel, "Colorimetric Determination of Traces of Metals," 3rd Edition, Interscience Publishers Inc., New York, 1959, p. 460.

[15] T. T. Gorsuch, "Radiochemical Investigations on the Recovery for Analysis of Trace Elements in Organic and Biological Materials," Analyst, Vol. 84, No. 996, 1959, pp. 135-173. doi:10.1039/an9598400135

[16] V. K. Malhotra, "Biochemistry for Students," 10th Edition, Jaypee Brothers Medical Publishers (P) Ltd., New Delhi, 1998.

[17] Natural Health Information Centre, "Iodine, Cupper. Medical Control, Modulation of Oestrogen and Foetal Health," 2012

http://www.natural-health-information-centre.com/calciu m.html

[18] Nutri Herb, "Dietary Supplement Shop, Health and Wellness Library: Zinc," 2012.

http://www.nutriherb.net/zinc.html

[19] V. W. Hays and M. J. Swenson, "Minerals and Bones," In: Dukes' Physiology of Domestic Animals, 10th Edition, Cornel University Press, Ithaca, 1985, pp. 449-466.

[20] R. K. Murray, D. K. Granner, P. A. Mayes and V. W. Rodwell, "Harper's Biochemistry," 25th Edition, McGrawHill, New York, 2000.

[21] D. M. Facchini, V. G. Yuen, M. L. Battell, J. H. McNeill and M. D. Grynpas, "The Effects of Vanadium Treatment 
on Bone in Diabetic and Non-Diabetic Rats," Bone, Vol. 38, No. 3, 2006, pp. 68-77.

[22] L. L. Hopkins Jr. and H. E. Mohr, "Vanadium as an Essential Nutrient," Federation Proceedings, Vol. 33, No. 6,
1974, pp. 1773-1775.

[23] Phyto trade Africa, "Ethical Sustainable Organic," 2009. http://www.phytotradeafrica.com 